Supremasi Hukum : Jurnal Penelitian Hukum

p-ISSN: 1693-766X ; e-ISSN: 2579-4663, Vol. 28, No. 2, Agustus 2019, 163-186

\title{
PEMILIHAN KEPALA DAERAH OLEH DEWAN PERWAKILAN RAKYAT DAERAH: SEBUAH KOMPARASI DENGAN PEMILIHAN SECARA LANGSUNG OLEH RAKYAT
}

\author{
Sayyidatul Insiyah \\ Fakultas Hukum Universitas Airlangga \\ sayyidinal.insiyah@gmail.com \\ Xavier Nugraha \\ nugrahaxavier72@gmail.com \\ Fakultas Hukum Universitas Airlangga \\ Shevierra Danmadiyah \\ shevierad.sd@gmail.com \\ Fakultas Hukum Universitas Airlangga
}

\begin{abstract}
The purpose of this research is to compare the direct election of regional heads by the people and the election of regional heads through the Regional House of Representatives, and the aspects that must be improved, which certainly is not only improvements to political parties. This study uses a normative legal research method, with the statutory approach, conceptual approach, and case approach. Based on the discussion of the weaknesses and strengths of the two regional head election mechanisms that have been carried out in Indonesia, the best regional head election mechanism is still to maintain the direct election mechanism by the people. Elections are the best way to carry out the process of changing positions in government.
\end{abstract}

Keywords: Comparison; Direct-election; People;

\begin{abstract}
Abstrak
Penelitian ini bertujuan untuk mengkomparasi antara pemilihan kepala daerah secara langsung oleh rakyat dengan pemilihan kepala daerah melalui DPRD, dan aspek-aspek yang harus dilakukan perbaikan, yang pasti tidak hanya perbaikan terhadap partai politik saja. Penelitian ini menggunakan metode penelitian hukum normatif, dengan pendekatan peraturan perundang-undangan, pendekatan konseptual, dan pendekatan kasus. Berdasarkan pembahasan atas kekurangan dan kelebihan kedua mekanisme pemilihan kepala daerah yang pernah dilakukan di Indonesia, mekanisme pemilihan kepala daerah yang terbaik adalah masih dengan tetap mempertahankan mekanisme pemilihan secara langsung oleh rakyat. Pemilihan umum merupakan cara yang terbaik untuk melakukan proses penggantian jabatan dalam pemerintahan.
\end{abstract}

Kata Kunci: Komparasi; Pemilihan-Langsung; Rakyat;

\section{PENDAHULUAN}

Dewasa ini, negara-negara modern dalam menjalankan pemerintahannya adalah berdasarkan atas hukum (Rechtsstaat) dan tidak berdasarkan atas kekuasan belaka

Sayyidatul Insiyah; Xavier Nugraha; Shevierra Danmadiyah, Pemilihan Kepala Daerah Oleh Dewan Perwakilan Rakyat Daerah: Sebuah Komparasi Dengan Pemilihan Secara Langsung Oleh Rakyat 
Supremasi Hukum : Jurnal Penelitian Hukum

p-ISSN: 1693-766X ; e-ISSN: 2579-4663, Vol. 28, No. 2, Agustus 2019, 163-186

(Machtsstaat). ${ }^{1} \mathrm{Hal}$ ini dilandasakan pada berkembangnya konsep perlindungan hukum yang telah mendunia, dan konsep absolutisme kekuasaan yang semakin memudar. ${ }^{2}$ Salah satu unsur esensial dari negara hukum adalah menjunjung tinggi adanya supermasi konstitusi. Hal ini adalah logis, karena di dalam konstitusi, umumnya terdapat pengaturan terkait elemen-eleman yang harus ada di dalam negara hukum. ${ }^{3}$ Selain menjunjung supremasi konstitusi di samping merupakan konsekuensi dari konsep negara hukum, umunya sistem pemerintahan demokrasi digunakan karena merupakan wujud perjanjian sosial tertinggi. ${ }^{4}$ Paham demokrasi sebagaimana teori yang dikemukakan oleh Abraham Lincoln bahwa "democracy is the government of the people, by the people, for the people," memiliki arti bahwa demokrasi merupakan pemerintahan dari rakyat, oleh rakyat, dan untuk rakyat. Begitu pula dengan Indonesia, dimana selain negara hukum, Indonesia adalah negara demokrasi. Paham negara hukum yang seperti ini dikenal dengan sebutan "negara hukum yang demokratis" (democratische rechtsstaat) 5 atau dalam bentuk konstitusional disebut constitutional democracy. 6 Salah satu negara hukum yang demokratis tersebut adalah Indonesia. Pernyataan Indonesia sebagai negara hukum yang demokratis termanifestasi dalam Undang- Undang Dasar Negara Republik Indonesia 1945 (selanjutnya disebut UUD NRI 1945 7) Pasal 1 ayat (1) yang

${ }^{1}$ Xavier Nugraha et al., Penggunaan Sistem Noken Di Papua Sebagai Wujud Pemilihan Kepala Daerah yang Demokratis Dalam Persektif UUD 1945, Yogyakarta: Penerbit Harfeey, Cet. 1, 2019, hlm. 93.

2 Ibid.

${ }^{3}$ Menurut Frederich Julius Stahl, negara hukum (rechtstaat) memiliki ciri-ciri 1. Adanya perlindungan terhadap hak asasi manusia 2. Adanya pemisahan dan pembagian kekuasaan Negara untuk menjamin perlindungan hak asasi manusia 3. Pemerintahan berdasarkan peraturan 4. Adanya peradilan administrasi, sedangkan menurut A. V. Dicey, cir-ciri negara hukum (rule of law) adalah 1. Supremacy of Law (Supremasi Hukum), 2. Equality before the Law (Persaman dalam kedudukan hukum bagi setiap orang). 3. Human Rights (Hak-hak Asasi Manusia), maka bisa dilihat bahwa terdapat persamaan terkait ciri-ciri negara hukum, baik rechtstaat, maupun rule of law, yaitu perlindungan hak asasi manusia dan pembatasan kekuasaan, yang umumnya tertuang di dalam konstitusi suatu negara, selanjutnya lihat Aloysius R. Entah, "Indonesia: Negara Hukum yang Berdasarkan Pancasila", Seminar Nasional Hukum, Vol 2, No 1, Juni 2016, hlm. 534-535.

${ }^{4}$ Muntoha, "Demokrasi dan Negara Hukum", Jurnal Konstitusi, Vol 6, No 3, Juni 2009, hlm. 152 .

5 Maruarar Siahaan, "Peran Mahkamah Konstitusi Dalam Penegakan Hukum Konstitusi", Jurnal Hukum, Vol 1, No 2, Maret 2009, hlm. 365.

${ }^{6}$ Jimly Asshiddiqie, Menuju Negara Hukum Yang Demokratis,Sekretariat Jenderal dan Kepaniteraan Mahkamah Konstiusi, Jakarta: Sekretariat Jendral Mahkamah Konstitusi, Cetakan 1, 2009, hlm. 690.

7 Penggunaan UUD NRI 1945 menunjukan bahwa Undang-Undang dasar tersebut merupakan Undang-Undang Dasae hasil amandemen, selanjutnya lihat Xavier Nugraha et.al.,"Rekonstruksi Batas Usia Minimal Perkawinan Sebagai Bentuk Perlindungan Hukum

Sayyidatul Insiyah; Xavier Nugraha; Shevierra Danmadiyah, Pemilihan Kepala Daerah Oleh Dewan Perwakilan Rakyat Daerah: Sebuah Komparasi Dengan Pemilihan Secara Langsung Oleh Rakyat 
Supremasi Hukum : Jurnal Penelitian Hukum

p-ISSN: 1693-766X ; e-ISSN: 2579-4663, Vol. 28, No. 2, Agustus 2019, 163-186

menyatakan "Negara Indonesia ialah Negara Kesatuan yang berbentuk Republik", Ayat (2) "Kedaulatan berada ditangan rakyat dan dilaksanakan menurut UndangUndang Dasar", dan Ayat (3) yang berbunyi "Negara Indonesia adalah Negara Hukum".8

Salah satu konsekuensi yuridis dari sistem negara hukum yang demokratis di Indonesia adalah adanya pemlihan pemimpin dengan cara yang demokratis. Pemilihan pemimpin tersebut, termasuk pemilihan pemimpin di daerah atau biasa dikenal sebagai kepala daerah. Pemilihan kepala daerah yang demokratis diatur dalam Pasal 18 ayat (4) UUD NRI 1945 yang berbunyi bahwa :

"Gubernur, Bupati dan Walikota masing-masing sebagai Kepala Pemerintahan Daerah Provinsi, Kabupaten dan Kota dipilih secara demokratis ".

Meskipun UUD NRI 1945 sebagai Staatsgrundgezets telah menganamatkan bahwa pemilihan kepala daerah haruslah dilaksanakan secara demokratis, namun tidak ada penjelasan lebih lanjut mengenai pemilihan yang dilaksanakan secara demokratis tersebut. Bahkan jika dilihat, secara historis, pemilihan kepala daerah yang demokratis tersebut memiliki beberapa wujud. Di dalam Undang-Undang No 5 tahun 1974 tentang Pokok-Pokok Pemerintahan Daerah, wujud pemilihan kepala daerah yang demokratis melalui pemilihan oleh Presiden berdasarkan rekomendasi oleh DPRD. Hal ini didasarkan, pada pendapat bahwa Presiden dipilih langsung oleh rakyat, sehingga ketika Presiden memilih Kepala Daerah secara langsung adalah logis, karena dianggap sebagai wujud perpanjangan tangan dari suara rakyat melalui Presiden tersebut.

Setelah berakhirnya rezim Orde Baru, dilakukan revisi atas sejumlah undangundang. Salah satunya, pemerintah mengundangkan Undang-Undang Nomor 22 Tahun 1999 tentang Pemerintahan Daerah. Apabila sebelumnya DPRD hanya mengusulkan nama dan kandidat kepala daerah yang kemudian diserahkan kepada Presiden, dan selanjutnya Presiden yang akan memutuskan diterima atau tidak usulan tersebut. Kali ini, DPRD mempunyai wewenang penuh terhadap terpilihnya kepala daerah. Pasca reformasi, pada Undang-Undang Nomor 22 Tahun 1999, konsep pemilihan kepala daerah yang dipilih oleh DPRD dianggap lebih demokratis, karena pemilihan oleh Presiden pada Undang-Undang Nomor 5 tahun 1974 ternyata menghasilkan kepala daerah yang menjadi boneka semata bagi Presiden dan tidak mementingkan kepentingan daerah. Dengan dasar tersebutlah, maka pemilihan

Terhadap Perempuan (Analisa Putusan MK No. 22/Puu-Xv/2017)”, Lex Scientia. Vol 3, No. 1, Juni 2019. hlm.43.

8 Jafrianto, "Eksistensi Pemilihan Dengan Model Kesepakatan Warga Dalam Sistem Pemilihan Umum Di Indonesia (Kajian Putusan Mahkamah Konstitusi Nomor 47-81/PHPU.AVII/2009 tentang Perselisihan Hasil Pemilihan Umum)", JOM Fakultas Hukum. Vol 3, No 2, Oktober 2016, hlm. 2.

Sayyidatul Insiyah; Xavier Nugraha; Shevierra Danmadiyah, Pemilihan Kepala Daerah Oleh Dewan Perwakilan Rakyat Daerah: Sebuah Komparasi Dengan Pemilihan Secara Langsung Oleh Rakyat 
Supremasi Hukum : Jurnal Penelitian Hukum

p-ISSN: 1693-766X ; e-ISSN: 2579-4663, Vol. 28, No. 2, Agustus 2019, 163-186

kepala daerah diserahkan ke DPRD yang dianggap adalah wakil rakyat di daerah pada saat itu.

Dalam praktiknya, ternyata pemilihan kepala daerah oleh DPRD digunakan sebagai sarana politik uang. Praktik pemilihan kepala daerah oleh DPRD tersebut ternyata digunakan untuk jual-beli jabatan oleh DPRD pada masa itu. Hal tersebut membuat masyrakat tidak lagi percaya pada lembaga negara untuk mewakili suara rakyat, sehingga masyarakat mengusulkan agar meletakkan pemilihan kepala daerah secara langsung kepada rakyat. Ini adalah salah satu hal yang melatarbelakangi Undang-Undang Nomor 32 Tahun 2004 tentang Pemerintahan Daerah mengatur agar pemilihan kepala daerah dilakukan secara langsung oleh masyarakat. ${ }^{9}$ Meskipun demikian, dalam Pasal 56 ayat (2), terdapat ketentuan yang menyaratkan agar Calon Kepala Daerah diusulkan oleh partai politik atau gabungan dari partai politik. Syarat ini dianggap masyarakat tidak sepenuhnya mendorong kesempatan terpilihnya kepala daerah yang benar-benar independen yang bebas dari kepentingan politik. Karena hal itulah, maka muncul Undang-Undang Nomor 12 Tahun 2008 tentang Perubahan atas Undang-Undang Nomor 32 Tahun 2004 tentang Pemerintahan Daerah. Dalam undang-undang ini, Kepala Daerah yang mencalonkan diri tidak harus bergabung atau masuk ke partai politik terlebih dahulu. Calon perseorangan diberi kesempatan untuk mendaftar, namun dengan syarat mendapat jumlah dukungan tertentu.

Pada tahun 2014, wacana pemilihan kepala daerah oleh DPRD kembali digaungkan. Hal ini dilandaskan pada pemikiran bahwa pemilihan kepala daerah secara langsung oleh rakyat ternyata tidak membuat money politic yang menjadi tujuan awal dari penyerahan pemilihan secara langsung kepada rakyat terwujud. Bahkan, money politic yang terjadi pada pemilihan umum dianggap lebih parah daripada ketika kepala daerah dipilih oleh DPRD. Wacana ini kemudian terealisasi di dalam Undang-Undang Nomor 22 Tahun 2014 tentang Pemilihan Gubernur, Bupati dan Walikota. Namun, penolakan yang begitu besar dari masyrakat yang menggangap hal tersebut adalah perwujudan dari kemunduran demokrasi, membuat Presiden melahirkan Peraturan Pemerintah Pengganti Undang-Undang Nomor 1 Tahun 2014 Tentang Pemilihan Gubernur, Bupati, Dan Walikota. ${ }^{10}$

Peraturan ini kemudian disahkan, melalui Undang-Undang Nomor 1 Tahun 2015 tetang penetapan Peraturan Pemerintah Pengganti Undang-Undang Nomor 1 Tahun 2014 tentang Pemilihan Gubernur, Bupati, Dan Walikota Menjadi Undang-

9 Pasal 24 ayat (5) jo. 56 ayat (1) Undang-Undang Nomor 32 Tahun 2004 Tentang Pemerintahan Daerah

10 Hal ini dapat dilihat dalam ketentuan menimbang huruf (a) Peraturan Pemerintah Pengganti Undang-Undang Nomor 1 Tahun 2014 Tentang Pemilihan Gubernur, Bupati, Dan Walikota yang menjelaskan bahwa kedaulatan rakyat serta demokrasi dari rakyat, oleh rakyat, dan untuk rakyat wajib dihormati sebagai syarat utama pelaksanaan pemilihan Gubernur, Bupati, dan Walikota;

Sayyidatul Insiyah; Xavier Nugraha; Shevierra Danmadiyah, Pemilihan Kepala Daerah Oleh Dewan Perwakilan Rakyat Daerah: Sebuah Komparasi Dengan Pemilihan Secara Langsung Oleh Rakyat 
Supremasi Hukum : Jurnal Penelitian Hukum

p-ISSN: 1693-766X ; e-ISSN: 2579-4663, Vol. 28, No. 2, Agustus 2019, 163-186

Undang. Sejak Undang-Undang tersebut disahkan, hingga Undang-Undang Nomor 10 Tahun 2016 tentang Perubahan Kedua atas Undang-Undang Nomor 1 Tahun 2015 tentang enetapan Peraturan Pemerintah Pengganti Undang-Undang Nomor 1 Tahun 2014 tentang Pemilihan Gubernur, Bupati, dan Walikota menjadi Undang-Undang disahkan, pemilihan Kepala Daerah masih diletakkan secara langsung kepada rakyat. Meskipun demikian, polemik pemilihan Kepala Daerah melalui DPRD ataupun tetap secara langsung oleh rakyat masih terus terjadi. Memang, jika dilihat dalam Putusan MK No. 72-73/PUU-II/2004 dan Putusan Mahkamah Konstitusi Nomor 97/PUUXI/2013, dijelaskan bahwa konsep pemilihan kepala yang demokratis adalah open legal policy dari pembuat Undang-Undang. Sehingga, baik dipilih oleh DPRD ataupun dipilih secara langsung oleh rakyat adalah sama-sama demokratis. Namun, meskipun keduanya adalah sama-sama demokratis, legislator dalam mengambil kebijakan, harus mempertimbangkan kebijakan mana yang lebih tepat dan mengungtungkan bagi masyrakat Indonesia. Hal ini sejatinya sesuai dengan postulat yang disampaikan oleh Thomas R Dye, yaitu "whatever government choose, to do or not to do, the most important is there must be a goal, objective or purpose"11

Berdasarkan hal tersebut, maka rumusan masalah dalam penelitian ini adalah: (1) Apa kelebihan dan kekurangan pemilihan kepala daerah secara langsung oleh rakyat ?; dan (2) Apa kelebihan dan kekurangan pemilihan kepala daerah oleh DPRD?Penelitian ini berbeda dengan penelitian-penelitian yang ada sebelumya. Misalnya, dalam penelitian Ali Marwan Hsb dengan judul Pemilihan Kepala Daerah yang Demokratis Berdasarkan Putusan Mahkamah Konstitsi Nomor 97/PUU-IX/2013 yang juga membahas terkait pemilihan kepala daerah. Dalam penelitian tersebut, penulis berangkat dari pendekatan peraturan perundang-undangan dan tidak mengkorelasikan dengan fakta tentang pemilihan kepala daerah yang ada saat ini. Hal ini berbeda dengan penelitian ini yang tidak hanya melihat bagaimana peraturan perundang-undangan, namun juga melihat fakta tentang pemilihan kepala daerah yang ada. Bahkan, dalam penelitian ini disajikan berbagai data dan kasus terkait pemilihan kepala daerah. Selain itu, penelitian yang dilakukan oleh Ali Marwan Hsb tidak berfokus pada bagaimana kelebihan dan kekurangan masing-masing dari pemilihan kepala daerah secara langsung maupun melalui DPRD. Sehingga, sampai pada kesimpulan penelitian tersebut tidak mengambil standing pemilihan kepala daerah demokratis seperti apa yang hendaknya dilakukan di Indonesia. Hal tersebut berbeda dengan penelitian ini yang mampu mengambil standing pemilihan kepala daerah secara langsung oleh rakyat dengan dasar-dasar yang jelas.

Selanjutnya penelitian Ridho Imawan Hanafi yang berjudul Pemilihan Langsung Kepala Daerah di Indonesia: Beberapa Catatan Kritis untuk Partai Politik.

11 Thomas R.Dye, Understanding Public Policy, New York: Pearson Education, Cet. 13, 2010, hlm. 3.

Sayyidatul Insiyah; Xavier Nugraha; Shevierra Danmadiyah, Pemilihan Kepala Daerah Oleh Dewan Perwakilan Rakyat Daerah: Sebuah Komparasi Dengan Pemilihan Secara Langsung Oleh Rakyat 
Supremasi Hukum : Jurnal Penelitian Hukum

p-ISSN: 1693-766X ; e-ISSN: 2579-4663, Vol. 28, No. 2, Agustus 2019, 163-186

Penelitian tersebut membahas mengenai beberapa persoalan terkait dengan peran partai politik pada pemilihan langsung kepala daerah. Sehingga, hal yang banyak dibahas adalah terkait bagaimana peran partai politik dan tidak banyak membahas mengenai sistem pemilihan umum yang seharusnya diterapkan. Penelitian tersebut tidak mengkomparasi dengan pemilihan kepala daerah oleh DPRD, melainkan langsung meneliti terkait masalah yang ada dalam pemlihan kepala daerah secara langsung oleh rakyat. Pembahasan mengenai demokrasi atau tidak lebih didasarkan pada bagaimana partai politik memainkan perannya, bukan dilihat dari sisi apakah dipilih langsung oleh rakyat atau dipilih melallui DPRD. Penelitian ini bertujuan untuk mengkomparasi antara pemilihan kepala daerah secara langsung oleh rakyat dengan pemilihan kepala daerah melalui DPRD, sehingga, dapat diketahui masingmasing kekurangan dan kelebihan diantara pemilihan kepala daerah secara langsung oleh rakyat dengan pemilihan kepala daerah melalui DPRD. Dengan diketahui masing-masing kekurangan dan kelebihan tersebut, akan dapat diketahui aspek apa yang harus dilakukan perbaikan, yang pasti tidak hanya perbaikan terhadap partai politik saja.

\section{METODE PENELITIAN}

Tulisan ini merupakan penelitian argumentasi hukum dengan memfokuskan ciri utama mengkaji pemberlakuan suatu kasus dengan disertai argumentasi/pertimbangan hukum yang dibuat penegak hukum, serta interpretasi di balik pemberlakuan tersebut. ${ }^{12}$ Penelitian ini dilakukan dengan penelitian normatif. Penelitian normatif adalah penelitian yang meletakkan hukum sebagai sebuah bangunan sistem norma, yang terdiri dari asas-asas, norma, kaidah dari peraturan perundangan, putusan pengadilan, perjanjian serta doktrin (ajaran). ${ }^{13}$ Penelitian normatif ini dilakukan dengan mengaji dan menaganalisa peraturan perundang-undangan ataupun bahan hukum lain yang berkaitan dengan sistem pemilihan kepala daerah di Indonesia.

Penelitian ini menggunakan pendekatan pendekatan peraturan perundangundangan (statute approach), pendekatan konseptual (conceptual approach), dan pendekatan kasus (case approach). Pendekatan perundang-undangan (statute approach) dilakukan dengan menelaah semua peraturan perundangundangan dan regulasi yang berkaitan dengan dengan isu hukum yang ditangani, sehingga dapat diketahui ratio legis, dasar ontologis dan landasan filosofis

${ }^{12}$ M.V.Hoecke, Legal doctrine: Which method(s) for what kind of discipline?, Oxford: HART Publishing, 2011, hlm. 16.

${ }^{13}$ Depri Liber Sonata, "Metode Penelitian Hukum Normatif dan Empiris: Karakteristik Khas Dari Metode Meneliti Hukum”, Fiat Justitia Jurnal Imu Hukum, Vol 8, No 1, 2017, hlm. 25.

Sayyidatul Insiyah; Xavier Nugraha; Shevierra Danmadiyah, Pemilihan Kepala Daerah Oleh Dewan Perwakilan Rakyat Daerah: Sebuah Komparasi Dengan Pemilihan Secara Langsung Oleh Rakyat 
Supremasi Hukum : Jurnal Penelitian Hukum

p-ISSN: 1693-766X ; e-ISSN: 2579-4663, Vol. 28, No. 2, Agustus 2019, 163-186

pengaturan yang berkaitan tentang pemilihan kepala daerah. ${ }^{14}$ Pengaturan tentang pemilihan kepala daerah tersebut, seperti Undang-Undang Nomor 32 Tahun 2004 tentang Pemerintahan Daerah, Undang-Undang Nomor 12 Tahun 2008 tentang Perubahan atas Undang-Undang Nomor 32 Tahun 2004 tentang Pemerintahan Daerah, Undang-Undang Nomor 23 Tahun 2014 tentang Pemerintah Daerah, UndangUndang Nomor 1 Tahun 2015 tentang Penetapan Peraturan Pemerintah Pengganti Undang-Undang Nomor 1 Tahun 2014 tentang Pemilihan Gubernur, Bupati, Dan Walikota Menjadi Undang-Undang, Undang-Undang Nomor 8 Tahun 2015 Perubahan atas Undang-Undang Nomor 1 Tahun 2015 tentang Penetapan Peraturan Pemerintah Pengganti Undang-Undang Nomor 1 Tahun 2014 tentang Pemilihan Gubernur, Bupati, dan Walikota menjadi Undang-Undang, Undang-Undang Nomor 10 Tahun 2016 tentang Perubahan Kedua atas Undang-Undang Nomor 1 Tahun 2015 tentang Penetapan Peraturan Pemerintah pengganti Undang-Undang Nomor 1 Tahun 2014 tentang Pemilihan Gubernur, Wupati, dan walikota menjadi Undang-Undang, dan sebagainya.

Pendekatan konseptual (conceptual approach) merupakan pendekatan yang beranjak dari pandangan-pandangan dan doktrin-doktrin yang berkembang di dalam ilmu hukum. ${ }^{15}$ Pendekatan ini dilakukan dengan pemahaman atas konsep yang dikemukakan para ahli yang terdapat di berbagai literature terutama yang terkait dengan pemilihan kepala daerah.

Pendekatan kasus (case approach) menggunakan putusan hakim sebagai sumber bahan hukum. Putusan hakim yang digunakan adalah putusan hakim yang telah memiliki kekuatan hukum tetap. ${ }^{16}$ Pada saat membahas putusan pengadilan sebagai bahan hukum primer telah dikatakan bahwa yang memiliki kekuatan hukum adalah pada bagian ratio decidendi-nya, yaitu alasan hukum yang digunakan oleh hakim dalam menentukan putusannya (pertimbangan hakim) yang tertuang dalam Putusan Mahkamah Konstitusi No. 72-73/PUU-II/2004 dan Putusan Mahkamah Konstitusi Nomor 97/PUU-XI/2013 tentang Pemilihan Kepala Daerah di Indonesia.

\section{HASIL DAN PEMBAHASAN}

\section{Kelebihan dan Kekurangan Sistem Pemilihan Kepala Daerah Secara Langsung}

Prof. Satjipto Rahardjo dalam teorinya Progresivitas Hukum menyatakan bahwa hukum tidaklah berjalan pada ruang hampa, namun hukum selalu berjalan

${ }^{14}$ Zayanti Mandasari, "Politik Hukum Pengaturan Masyarakat Hukum Adat (Studi Putusan Mahkamah Konstitusi", Jurnal Hukum IUS QUIA IUSTUM, Vol 2, No 1, 2014, hlm. 231.

15 Zulfadli Barus, "Analisis Filosofis Tentang Peta Konseptual Penelitian Hukum Normatif Dan Penelitian Hukum Sosiologis", Jurnal Dinamika Hukum, Vol 13, No 2, 2014, hlm. 313.

16 Oly Vina Agustine, "Jurisprudence Enforceability on Judicial Review Authority in the Constitutional Court Decision”, Jurnal Konstitusi, Vol 15, No 3, 2018, hlm. 644.

Sayyidatul Insiyah; Xavier Nugraha; Shevierra Danmadiyah, Pemilihan Kepala Daerah Oleh Dewan Perwakilan Rakyat Daerah: Sebuah Komparasi Dengan Pemilihan Secara Langsung Oleh Rakyat 
Supremasi Hukum : Jurnal Penelitian Hukum

p-ISSN: 1693-766X ; e-ISSN: 2579-4663, Vol. 28, No. 2, Agustus 2019, 163-186

mengikuti dinamika masyarakat. ${ }^{17}$ Apabila dikaitkan dengan fakta konstelasi politik saat ini, pemilihan kepala daerah secara langsung ternyata tidak sepenuhnya memberikan keuntungan bagi demokrasi Indonesia. Pemilihan kepala daerah secara langsung melalui pemilihan umum ternyata juga mengandung beberapa kelemahankelemahan. Adapun beberapa kelemahan dari pemilihan umum tersebut yang sangat sering terjadi dalam masyarakat adalah banyaknya konflik horizontal yang timbul akibat pemilihan umum serta tingkat partisipasi masyarakat yang masih rendah.

\section{a. Kelebihan Pemilihan Kepala Daerah Secara Langsung oleh Rakyat}

Pemilihan umum adalah pranata terpenting dalam tiap negara demokrasi terlebih bagi negara dengan berbentuk republik. ${ }^{18}$ Pelaksanaan pemilihan umum juga merupakan salah satu sarana penyaluran hak asasi warga negara yang sangat prinsipil. Oleh karenanya, dalam rangka pelaksanaan hak-hak asasi warga negara adalah keharusan bagi pemerintah untuk menjamin terlaksananya penyelenggaraan pemilihan umum sesuai dengan jadwal ketatanegaraan yang telah ditentukan. ${ }^{19}$ Selain itu, adanya supremasi konstitusi yang meletakkan rakyat sebagai pelaksanaan kedaulatan tertinggi melahirkan konsekuensi bahwa setiap warga negara berhak ikut aktif dalam setiap proses pengambilan keputusan kenegaraan. ${ }^{20}$ Sehingga, adanya pemilihan umum sebenarnya merupakan suatu kewajiban konstitusional bagi negara untuk kemudian memberikan ruang bagi masyarakat untuk dapat menyalurkan hak pilihnya dalam pelaksanaan pemilihan umum.

Betapapun pemilihan kepala daerah oleh DPRD dimaksudkan sebagai mekanisme politik untuk mengejar efisiensi baik efisiensi waktu maupun anggaran, namun perlu dipahami pula bahwa agar pemerintahan nantinya dapat berlangsung secara efektif dan efisien, pemilihan kepala daerah harus pula melihat dari sisi penerimaan masyarakat. Sejalan dengan Prof. Jimmly Asshiddiqie bahwa dalam negara dengan sistem demokrasi modern, legalitas dan legitimasi pemerintahan merupakan faktor yang sangat penting dimana selain sebuah pemerintahan tersebut harus legal, pemerintahan tersebut juga harus legitimate. ${ }^{21}$ Artinya bahwa memang suatu pemerintahan yang terbentuk tidak hanya harus didasarkan pada hukum semata, namun pemerintahan itu juga harus mendapat legitimasi atau penerimaan yang kuat dari rakyat, terlebih rakyat daerah itu sendiri. Legitimasi politik dari rakyat tersebut memiliki peranan penting dalam mempengaruhi, meyakinkan, atau memperbarui adanya kesepakatan-kesepakatan politik antara pemerintah dengan

17 Satjipto Rahardjo, Biarkan Hukum Mengalir, Jakarta: Kompas, 2007, hlm. 139.

${ }^{18}$ Tim Peneliti Sistem Pemilu, Sistem Pemilihan Umum di Indonesia, Jakarta: Lembaga Ilmu Pengetahuan Indonesia dan Pustaka Sinar Harapan, 1998, hlm. 2.

${ }_{19}$ Jimly Asshiddiqie, Pengantar Imu Hukum Tata Negara, Jakarta: RajaGrafindo Persada, 2009, hlm. 416.

20 Dahlan Thaib, Ketatanegaraan Indonesia Perspektif Konstitusional, Yogyakarta: Total Media, 2009, hlm. 89.

21 Jimly Asshiddiqie, Op.cit., hlm. 417.

Sayyidatul Insiyah; Xavier Nugraha; Shevierra Danmadiyah, Pemilihan Kepala Daerah Oleh Dewan Perwakilan Rakyat Daerah: Sebuah Komparasi Dengan Pemilihan Secara Langsung Oleh Rakyat 
Supremasi Hukum : Jurnal Penelitian Hukum

p-ISSN: 1693-766X ; e-ISSN: 2579-4663, Vol. 28, No. 2, Agustus 2019, 163-186

rakyat di daerah karena dalam demokrasi modern, para penguasa dituntut untuk mengadakan kesepakatan dari rakyat daripada melalui pemaksaan (coercion) untuk mempertahankan legitimasinya. ${ }^{22}$

Landasan bahwasanya pemilu sebagai salah satu instrument panting dalam sistem demokrasi juga ditegaskan oleh Joseph Schumpter dimana Schumpter mendefiniskan demokrasi secara prosedural berkaitan derat dengan pemilu sebagai esensi demokrasi. ${ }^{23}$ Artinya, bahwa pemilihan kepala daerah secara langsung merupakan bentuk pengejawantahan partisipasi politik rakyat daerah yang akan menentukan sendiri bagaimana figur pemimpin daerah sesuai dengan harapan rakyat di daerah. Mengingat salah satu alasan penting perlunya pemilihan langsung kepala daerah adalah bahwa pemilu lebih membuka peluang tampilnya calon pemimpin yang sesuai dengan kehendak mayoritas rakyat. ${ }^{24}$ Dengan demikian, akan menjadi suatu kontradiksi apabila suatu pemerintah menyatakan diri sebagai pemerintahan demokrasi namun pembentukannya justru tidak berlandaskan pada hasil pemilihan umum.

Pemilihan umum selain merupakan mekanisme bagi rakyat untuk memilih para wakil juga dapat dilihat sebagai proses evaluasi dan pembentukan kembali kontrak sosial. ${ }^{25}$ Kekuasaan tertinggi di tangan rakyat itu dibatasi oleh kesepakatan yang mereka tentukan sendiri secara bersama-sama yang dituangkan dalam aturan hukum yang berpuncak pada rumusan konstitusi sebagai produk kesepakatan tertinggi dari seluruh rakyat. ${ }^{26}$ Melalui pemilu, rakyat akan menyerahkan sebagain haknya terutama hak yang berkaitan dengan ekonomi, sosial, dan budayanya kepada

Adanya pemilu yang melibatkan masyarakat secara langsung pada hakikatnya akan lebih mengakomodir adanya satu ruang partisipasi masyarakat secara langsung dalam penyelenggaraan pemerintahan daerah. Terbukanya ruang partisipasi langsung akan berpotensi semakin dekatnya hubungan antara kepala daerah dengan masyarakat di daerah. Dengan demikian maka aspirasi, agregasi, dan artikulasi suara rakyat dapat dengan mudah tersalurkan kepada kepala daerah terpilih, karena rakyat memilih kepala daerah secara langsung sehingga dapat lebih mudah dalam menyuarakan berbagai kehendak dan keinginan masyarakat di daerah.

22 Janpatar Simamora, "Eksistensi Pemilukada Dalam Rangka Mewujudkan Pemerintahan Daerah Yang Demokratis", Jurnal Mimbar Hukum, Vol 23, No 1 Februari 2011, hlm. 227.

${ }^{23}$ Huntington dalam Aidul Fitriaciada Azhari, "Reformasi Pemilu dan Agenda Konsolidasi Demokrasi: Perspektif Ketatanegaraan", Jurisprudence, Vol 1, No 2, September 2004, hlm. 180.

${ }^{24}$ Mahfud MD, 2007, Perdebatan Hukum Tata Negara Pasca Amandemen Konstitusi, Jakarta: Pustaka LP3ES Indonesia, hlm. 133-135.

${ }^{25}$ Evi Purnama Wati, "Pemilu Sebagai Wujud Kedaulatan Rakyat", E-Jurnal Hukum, Vol 8, No 2, Mei 2015, hlm. 194.

${ }^{26}$ Martha Pigome, "Implementasi Prinsip Demokrasi dan Nomokrasi dalam Struktur Ketatatanegaraan RI Pasca Amandemen UUD 1945”, Jurnal Dinamika, Vol 11, No 2, 2011, hlm. 336.

Sayyidatul Insiyah; Xavier Nugraha; Shevierra Danmadiyah, Pemilihan Kepala Daerah Oleh Dewan Perwakilan Rakyat Daerah: Sebuah Komparasi Dengan Pemilihan Secara Langsung Oleh Rakyat 
Supremasi Hukum : Jurnal Penelitian Hukum

p-ISSN: 1693-766X ; e-ISSN: 2579-4663, Vol. 28, No. 2, Agustus 2019, 163-186

Pun, melalui pemilihan umum, kepala daerah akan merasa bertanggung jawab secara moril karena merasa dipilih secara langsung oleh rakyat. Adanya pemilihan umum juga sebenarnya berfungsi sebagai sarana membatasi perilaku dan kebijakan pemerintah. Penguasa-penguasa yang agendanya tidak lagi disetujui rakyat maka dapat dikontrol perilakunya secara periodik dalam pemilu berikutnya dengan cara pengalihan suara kepada kandidat atau partai lain yang dianggap lebih aspiratif. ${ }^{27}$

\section{b. Kekurangan Pemilihan Kepala Daerah Secara Langsung oleh Rakyat}

Pilihan berdemokrasi secara langsung melalui pemilihan umum nyatanya memunculkan celah bagi demokrasi Indonesia. Tiga kali melangsungkan pemilihan umum kepala daerah semenjak 2004 hingga pemilu kepala daerah 2009, ternyata memberikan catatan hitam bagi keberlangsungan pemilu itu sendiri. Adanya pemilu justru menimbulkan berbagai konflik horizontal dalam masyarakat. Data empiris Kementrian Dalam Negeri pada tahun 2005 hingga 2013 menyatakan bahwa setidaknya telah terdapat 50 korban jiwa akibat kerusuhan pemilukada yang dipicu ketidakpuasan terhadap hasil Pemilukada di seluruh Indonesia.28 Tidak hanya itu, sebanyak 57 orang tewas dalam bentrok pemilihan umum kepala daerah 2011 di Ilaga, Kabupaten Puncak Papua dimana bentrokan melibatkan dua kubu pasangan calon. ${ }^{29}$ Kasus yang terbaru ialah bentrok dua kubu tim sukses pasangan calon Bupati Empat Lawang, Sumatera Selatan yang terjadi pada 12 Juni 2018 yang mengakibatkan satu orang tewas akibat luka tembak serta tiga orang lainnya terluka. ${ }^{30}$

Berbagai fakta empiris tersebut menegaskan bahwa pemilihan umum memang sangat rawan menimbulkan konflik horizontal dalam masyarakat. Sungguh sangat disayangkan ketika kemudian tujuan mulia diselenggarakannya pesta demokrasi justru menggerus hak hidup beberapa masyarakat Indonesia. Sehingga wacana dipilihnya Kepala Daerah oleh DPRD kembali adalah dalam rangka menekan angka konflik masyarakat dimana ketika kepala daerah kemudian dipilih oleh DPRD, tentu potensi bentrok antar dua kubu akan terhindar karena pihak yang akan memilih kepala daerah bukanlah masyarakat perseorangan, namun DPRD yang

27 Sigit Pamungkas, Perihal Pemilu, Yogyakarta: Laboratorium Jurusan Ilmu Pemerintahan dan Jurusan Ilmu Pemerintahan Universitas Gadjah Mada, 2009, hlm. 5.

28 , "Mendagri: 50 Tewas Akibat Kerusuhan Pemilu Kada", https://news.detik.com/berita/d-2208294/mendagri-50-tewas-akibat-kerusuhan-pemilukada, 01 April 2013, dikunjungi pada 16 Juli 2019.

29 Jerry Omona, "Korban Tewas Akibat Pilkada Papua Capai 57 Orang", nasional.tempo.co/amp/382617/korban-tewas-akibat-pilkada-papua-capai-57-orang, 8 Februari 2012, dikunjungi pada 08 Oktober 2018.

30 Aji YK Putra, "2 Timses Calon di Pilkada Empat Lawang Dikabarkan Tewa", https://regional.kompas.com/read/2018/06/12/22040101/2-timses-calon-di-pilkada-empatlawang-bentrok-1-orang-dikabarkan-tewas?page=all, 12 Juni 2018, dikunjungi pada 16 Juli 2019.

Sayyidatul Insiyah; Xavier Nugraha; Shevierra Danmadiyah, Pemilihan Kepala Daerah Oleh Dewan Perwakilan Rakyat Daerah: Sebuah Komparasi Dengan Pemilihan Secara Langsung Oleh Rakyat 
Supremasi Hukum : Jurnal Penelitian Hukum

p-ISSN: 1693-766X ; e-ISSN: 2579-4663, Vol. 28, No. 2, Agustus 2019, 163-186

tentunya dalam proses pemilihannya harus pula melibatkan pastisipasi masyarakat daerah.

Tidak hanya konflik masyarakat, diselenggarakannya pemilukada secara langsung juga telah memakan anggaran yang sangat besar. Sebagai contoh ialah Pilkada Jawa Timur 2018 dimana anggaran yang diajukan oleh KPU ialah sebesar 817 miliar untuk pemilihan umum Gubernur, Bupati, dan Walikota di Jawa Timur. ${ }^{31}$ Sungguh angka yang fantastis bahwa hanya untuk menyelenggarakan pemilukada di satu daerah provinsi saja hingga menghabiskan ratusan triliun rupiah. Padahal, di lain sektor, beberapa daerah di Jawa Timur masih memerlukan adanya perbaikan dan pembangunan. Seperti contoh adalah di Kota Surabaya. Saat ini, Surabaya sedang membutuhkan pembangunan rumah sakit baru yang dikelola pemerintah, dimana jumlah pasien yang membutuhkan pengobatan ternyata tidak sebanding dengan jumlah kamar yang tersedia. ${ }^{32}$ Akibatnya, jumlah pasien membludak. Anggota Komisis B DPRD Kota Surabaya, Baktiono, menyatakan bahwa biaya yang dibutuhkan untuk membangun sebuah rumah sakit di Surabaya ialah sebesar 300 miliar rupiah. ${ }^{33}$ Apabila kemudian biaya pemilukada kota Surabaya sebesar 817 miliar tersebut dialokasikan untuk biaya pembangunan rumah sakit daerah, tentu dengan demikian akan membantu mewujudkan kesejahteraan masyarakat Surabaya. Terlebih bahwa dalam Pasal 34 ayat (3) UUD NRI 1945 bahwa "Negara bertanggung jawab atas penyediaan fasilitas pelayanan kesehatan dan fasilitas pelayanan umum yang layak." 34 Maka bukanlah sebuah kemustahilan ketika kemudian biaya pemilukada dialokasikan untuk kepentingan fasilitas umum, dan terkait pemilihan kepala daerah akan menjadi tugas DPRD. Belum lagi, apabila kemudian pemilihan kepala daerah tersebut dilaksanakan dalam dua putaran. Seperti contoh terjadinya dua putaran pemilukada Kota Surabaya 2004, KPUD Surabaya telah menganggarkan biaya Pilkada sebesar 32 miliar dimana untuk sekali putaran pemilihan Gubernur Surabaya, anggarannya dipatok Rp. 24 miliar. ${ }^{35}$

31 Ahmad Winarno, "Rp 817 Miliar, Anggaran untuk Pilkada Jatim 2018", https://regional.kompas.com/read/2017/06/03/12140131/rp.817.miliar.anggaran.untuk.pil kada.jatim.2018, 03 Juni 2017, dikunjungi pada 16 Juli 2019.

32 Abdul Hakim, "Rencana Pembangunan RSUD di Kawasan Surabaya Timur Masih Dikaji”, $\quad$ https://jatim.antaranews.com/berita/300553/rencana-pembangunan-rsud-dikawasan-surabaya-timur-masih-dikaji, 16 Juni 2019, 16 Juli 2019.

${ }^{33}$ Bayu Hermawan, "Berencana Bangun 7 Rumah Sakit, RS Mitra Incar Dana IPO Rp 4 Triliun", https://republika.co.id/berita/ekonomi/makro/15/02/27/nkfo4m-berencanabangun-7-rumah-sakit-rs-mitra-incar-dana-ipo-rp4-triliun, 27 Februari 2015, dikunjungi pada 16 Juli 2019.

${ }^{34}$ Undang-Undang Dasar Negara Republik Indonesia Tahun 1945, Op.cit., Ps 34 ayat (3).

35 Kacung Marijan, Pemilihan Kepala Daerah Secara Langsung dan Demokratisasi di Daerah, Surabaya: Airlangga University Press, 2005, hlm. 10.

Sayyidatul Insiyah; Xavier Nugraha; Shevierra Danmadiyah, Pemilihan Kepala Daerah Oleh Dewan Perwakilan Rakyat Daerah: Sebuah Komparasi Dengan Pemilihan Secara Langsung Oleh Rakyat 
Supremasi Hukum : Jurnal Penelitian Hukum

p-ISSN: 1693-766X ; e-ISSN: 2579-4663, Vol. 28, No. 2, Agustus 2019, 163-186

Berbagai penjelasan tersebut sejatinya mengerucutkan pada teori Analisis Ekonomi Terhadap Hukum (Economic Analysis of Law) dimana teori tersebut menjelaskan tentang penggunaan konsep-konsep ekonomi guna mengkaji dan menjelaskan efek dan akibat-akibat penerapan hukum tertentu, apakah penerapan hukum yang dimaksud telah efisien secara ekonomi serta mampu memberikan manfaat yang paling maksimal bagi masyarakat tanpa mengorbankan fungsi hukum yang sesungguhnya. ${ }^{36}$ Apabila kemudian teori tersebut dikaitkan dengan pelaksanaan pemilukada, dapat ditarik benang merah bahwasanya penerapan hukum, dalam hal ini ialah pengejawantahan konsep demokrasi melalui pemilihan umum kepala daerah sejatinya tidak dapat dikatakan efisien secara ekonomi, mengingat biaya yang dikeluarkan ternyata tidak sebanding dengan hasil yang diharapkan. Mengapa? Pemilihan umum kepala daerah ternyata tidak mampu menjamin kepala daerah terpilih benar-benar dapat mewakili aspirasi rakyat daerah. Hal ini terbukti dengan banyaknya kasus korupsi yang terjadi di kalangan elit kepala daerah. Sebagaimana yang telah terjadi saat ini dimana juru bicara Komisi Pemberatasan Korupsi (KPK) Febri Diansyah menyatakan bahwa pada tahun 2018 ini, KPK telah menangkap 15 kepala daerah. 37 Berbagai penjelasan tersebut bermuara pada satu kesimpulan bahwa praktik pemilu kerap hanya dijadikan tameng untuk menunjukkan bahwa sebuah sistem politik adalah demokratis dimana kebanyakan pemilu seringkali dilaksanakan lebih sebagai formalitas politik semata. ${ }^{38}$

Catatan hitam tentang pemilukada tidak hanya menyoal konflik horizontal masyarakat semata namun juga masalah rendahnya pasrtisipasi dan kesadaran politik masyarakat Indonesia yang tercermin dalam angka golput yang masih sangat tinggi. Sebagai contoh pada pemilukada serentak 2015, dimana pada pemilukada walikota Medan, partisipasi masyarakat Medan hanya sebesar 26,88 \%. 39 Artinya bahwa lebih dari separuh atau sebesar tiga per empat warga Medan memilih untuk tidak menggunakan hak pilihnya secara baik. Pemilu sebagai sarana pencerdasan dan penyadaran politik warga ${ }^{40}$ Pemilihan umum yang digadang-gadang mampu memberikan pembelajaran politik bagi masyarakat dan mengharap dipilihnya kepala daerah dari tangan masyarakat sendiri nyatanya masih terdapat fakta banyaknya

36Johnny Ibrahim, Pendekatan Ekonomi terhadap Hukum, Surabaya: Institute Teknologi Sepuluh Nopember Surabaya, 2009, hlm. 245.

${ }^{37}$ Dylan Aprialdo Rachman, "Modus Korupsi 32 Kepala Daerah yang Sudah Ditangkap KPK". https://nasional.kompas.com/read/2018/08/05/10101301/modus-korupsi-32-kepaladaerah-yang-sudah-ditangkap-kpk, 5 Agustus 2018, dikunjungi pada tanggal 09 Oktober 2018.

${ }^{38}$ Eep Saefulloh Fatah, Evaluasi Pemilu Orde Baru, Bandung: Mizan, 1997, hlm. 18

39 Kiagus Aulianshah, "Kepala Daerah Rajin Korupsi, Masyarakat Apolitis", https://beritagar.id/artikel/editorial/kepala-daerah-rajin-korupsi-masyarakat-apolitis, $\quad 21$ Desember 2015, dikunjungi pada 16 Juli 2017.

${ }^{40}$ Ali Marwan, Op.cit., hlm. 228.

Sayyidatul Insiyah; Xavier Nugraha; Shevierra Danmadiyah, Pemilihan Kepala Daerah Oleh Dewan Perwakilan Rakyat Daerah: Sebuah Komparasi Dengan Pemilihan Secara Langsung Oleh Rakyat 
Supremasi Hukum : Jurnal Penelitian Hukum

p-ISSN: 1693-766X ; e-ISSN: 2579-4663, Vol. 28, No. 2, Agustus 2019, 163-186

masyarakat yang masih bersikap acuh terhadap pelaksanaan demokrasi tersebut. Oleh kerenanya, gagasan dipilihnya kepala daerah oleh DPRD menurut beberapa tokoh politik dan hukum dirasa sebagai upaya yang lebih baik dalam mendapatkan sosok pemimpin daerah yang lebih baik, pun pemilihan oleh DPRD sejatinya tidak menciderai prinsip-prinsip demokrasi dan masih dalam koridor konstitusi.

\section{Kelebihan dan Kekurangan Sistem Pemilihan Kepala Daerah oleh DPRD}

Berdasarkan Pasal 18 ayat (3) UUD NRI Tahun 1945, DPRD merupakan salah satu unsur dalam pemerintahan daerah yang anggota-anggotanya dipilih melalui pemilihan umum. Sehingga, dapat diketahui bahwa DPRD merupakan representasi dari rakyat di daerah. Representasi secara sederhana bisa diartikan sebagai menghadirkan yang tidak hadir. ${ }^{41}$ Jika melihat konsep representasi yang diuraikan oleh Hanna F. Pitkin melalui bukunya The Concept of Representation, ia menuangkan gagasan/teori representasi politik yang melibatkan 'election' atau pemilihan sebagai lembaga yang utama di dalam pemerintahan perwakilan. ${ }^{42}$ Dalam hal ini, DPRD merupakan wujud dari perwakilan rakyat, dimana rakyat tidak hadir secara nyata tetapi diwakili oleh DPRD. Atas hal tersebut, DPRD merupakan lembaga penyalur aspirasi rakyat kepada pemerintah daerah.

\section{a. Kelebihan Pemilihan Kepala daerah oleh DPRD}

Pemilihan kepala daerah oleh DPRD bukan merupakan suatu hal yang baru di Indonesia. Undang-Undang Nomor 5 Tahun 1974 tentang Pokok-Pokok Pemerintahan di Daerah merupakan undang-undang pertama yang menggagas pemilihan kepala daerah oleh DPRD. ${ }^{43}$ Namun, dalam undang-undang tersebut, DPRD tidak sepenuhnya bisa dikatakan sebagai institusi yang memilih kepala daerah. Hal tersebut dikarenakan pada proses akhir pengangkatan, Menteri Dalam Negeri merupakan institusi yang berwenang untuk memilih dan mengangkat salah satu calon kepala daerah yang diajukan oleh DPRD. ${ }^{44}$

Keberadaan undang-undang tersebut, kemudian digantikan dengan UndangUndang Nomor 22 Tahun 1999 tentang Pemerintahan Daerah. Melalui undangundang ini, DPRD memiliki kewenangan yang penuh terkait pemilihan kepala daerah. Hal tersebut tercermin dari keberadaan DPRD sejak proses awal pencalonan sampai

41 Esty Ekawati, Dari Representasi Politik Formal ke Representasi Politik Non-Elektoral, Jurnal Penelitian Politik, Vol. 11, No. 2, Desember 2014, hlm. 130.

42 Ibid.

43 Ali Marwan Hsb , "Pemilihan Kepala Daerah Yang Demokratis Berdasarkan Putusan Mahkamah Konstitusi Nomor 97/PUU-IX/2013 (The Democratic of Regional Election Based on Constitutional Court Decisions Number 97/PUU-IX/2013)”, Jurnal Legislasi Indonesia, Vol. 13, No. 3, September 2016, hlm. 229.

44 Pasal 15 Undang-Undang Nomor 5 Tahun 1974 tentang Pokok-Pokok Pemerintahan di Daerah

Sayyidatul Insiyah; Xavier Nugraha; Shevierra Danmadiyah, Pemilihan Kepala Daerah Oleh Dewan Perwakilan Rakyat Daerah: Sebuah Komparasi Dengan Pemilihan Secara Langsung Oleh Rakyat 
Supremasi Hukum : Jurnal Penelitian Hukum

p-ISSN: 1693-766X ; e-ISSN: 2579-4663, Vol. 28, No. 2, Agustus 2019, 163-186

dengan penetapan pemenang. ${ }^{45}$ Namun, melalui Undang-Undang Nomor 23 Tahun 2004 tentang Pemerintahan Daerah, kewenangan DPRD tersebut telah dihapus dan digantikan dengan pemilihan kepala daerah secara langsung. ${ }^{46}$

Pada tahun 2014, kembali muncul keberadaan DPRD dalam pemilihan kepala daerah. Hal tersebut dimulai dengan diundangkannya Undang-Undang Nomor 22 Tahun 2014 tentang Pemilihan Gubernur, Bupati dan Walikota. Pada saat pembahasan rancangan undang-undang, gagasan kembali dipilihnya kepala daerah oleh DPRD ini mengemuka sebagai hasil evaluasi dari praktik pelaksanaan pemilihan kepala daerah yang dijalankan sejak berlakunya Undang-Undang Nomor 32 Tahun 2004 tentang Pemerintahan Daerah. ${ }^{47}$ Setidaknya, terdapat dua argumentasi utama yang melatarbelakangi gagasan kembali dipilihnya Kepala daerah oleh DPRD: Pertama, pelaksanaan pemilihan kepala daerah membutuhkan biaya sangat besar, baik biaya yang dikeluarkan oleh negara melalui penyelenggara pemilihan kepala daerah, maupun biaya yang dikeluarkan oleh pasangan calon; dan Kedua, praktik pemilihan kepala daerah yang diwarnai dengan politik uang, mulai dari yang besifat sporadis hingga yang bersifat masif, terstruktur, dan sistematis. ${ }^{48}$

Berkaitan dengan pembiayaan, pemilihan kepala daerah secara langsung membutuhkan anggaran APBN yang tidak sedikit. Meskipun, saat ini Pemerintah telah menginisiasi pemilihan kepala daerah secara serentak untuk menekan anggaran. Namun, Kementerian Dalam Negeri justru menyatakan bahwa penyelenggaraan pemilihan kepala daerah secara serentak lebih boros dibandingkan pemilihan kepala daerah yang waktunya disesuaikan oleh masing-masing daerah. 49 Pada tahun 2018, pemilihan kepala daerah secara langsung di 171 daerah membutuhkan biaya $\mathrm{Rp} 20$ triliun. 50 Sayangnya, biaya besar tak kunjung mendekatkan pemilihan kepala daerah kepada esensinya, yakni memperoleh kepala daerah yang terbaik. Bahkan, Komisi Pemberantasan Korupsi (KPK) mencatat telah terdapat 29 kepala daerah yang terjerat dugaan kasus korupsi sepanjang tahun 2018.51

45 Pasal 38-40 Undang-Undang Nomor 22 Tahun 1999 tentang Pemerintahan Daerah

46 Pasal 56 Undang-Undang Nomor 32 Tahun 2004 tentang Pemerintahan Daerah.

47 Janedjri M. Gaffar, Politik Hukum Pemilu, Jakarta: Konstitusi Press, 2012, hlm. 134.

48 Ibid, hlm. 134-135.

49 Safyra Primadhyta, Menteri Tjahjo: Pilkada Serentak Malah Boros Biaya, https://www.cnnindonesia.com/ekonomi/20180122132009-532-270670/menteri-tjahjopilkada-serentak-malah-boros-biaya, 22 Januari 2018, diakses pada 18 Juli 2019.

$50 \quad$ Biaya Tinggi Pemilihan Kepala Daerah, https://kolom.tempo.co/read/1100242/biaya-tinggi-pemilihan-kepala-daerah/full\&view=ok, 25 Juni 2018, diakses pada 18 Juli 2019

51 Dylan Aprialdo Rachman, Kaleidoskop 2018: 29 Kepala Daerah Terjerat Kasus Korupsi, https://nasional.kompas.com/read/2018/12/18/12495661/kaleidoskop-2018-29kepala-daerah-terjerat-kasus-korupsi?page=all, 18 Desember 2018, diakses pada 18 Juli 2019.

Sayyidatul Insiyah; Xavier Nugraha; Shevierra Danmadiyah, Pemilihan Kepala Daerah Oleh Dewan Perwakilan Rakyat Daerah: Sebuah Komparasi Dengan Pemilihan Secara Langsung Oleh Rakyat 
Supremasi Hukum : Jurnal Penelitian Hukum

p-ISSN: 1693-766X ; e-ISSN: 2579-4663, Vol. 28, No. 2, Agustus 2019, 163-186

Hal ini akan berbeda jika pemilihan kepala daerah dilakukan melalui DPRD. Dengan pemilihan kepala daerah oleh DPRD, hanya akan melibatkan para anggota DPRD yang jumlahnya hanya sebanyak 20-55 orang untuk DPRD kabupaten/kota ${ }^{2}$ dan sebanyak 35-120 orang untuk DPRD provinsi ${ }^{53}$. Berkaca pada hal tersebut, tentu Pemerintah tidak perlu mengeluarkan biaya sebesar yang dikeluarkan jika pemilihan kepala daerah dilakukan secara langsung. Atas perbandingan pengeluaran pemilihan Kepala daerah secara langsung dan melalui DPRD, maka perlu dilakukan analisis dengan economic analysis of law. Berdasarkan teori tersebut, perlu digunakan konsep-konsep ekonomi guna mengkaji dan menjelaskan efek dan akibat-akibat penerapan hukum tertentu, apakah penerapan hukum yang dimaksud telah efisien secara ekonomi serta mampu memberikan manfaat yang paling maksimal bagi masyarakat tanpa mengorbankan fungsi hukum yang sesungguhnya. ${ }^{54}$ Pemilihan kepala daerah melalui DPRD merupakan gagasan efisien dan mampu memberikan manfaat bagi masyarakat tanpa mengorbankan fungsi hukum dalam pemilihan kepala daerah. Tentu, fungsi pemilihan kepala daerah adalah memilih calon kepala daerah yang terbaik. Melalui DPRD yang notabene merupakan orang-orang berpendidikan, maka akan lebih bisa ditemukan calon kepala daerah yang sesuai. Selain itu, tidak dapat disangkal bahwa DPRD merupakan institusi yang secara hukum dan politis dipilih oleh rakyat, sehingga DPRD merupakan wakil rakyat yang mempunyai tanggung jawab menampung aspirasi masyarakat. 55 Bahkan, tidak dapat dipungkiri jika DPRD merupakan representasi dari rakyat yang ada di daerahnya.

Selanjutnya, berkaitan dengan politik uang, tidak jarang para calon kepala daerah menggunakannya sebagai salah satu strategi politik. Hal tersebut dikarenakan para calon berlomba-lomba untuk memperoleh suara dari rakyat. Bahkan, dalam pemilahan umum kepala daerah tahun 2018, Polri berhasil memproses 25 kasus politik uang selama pemilihan kepala daerah serentak tahun 2018 ini. ${ }^{56}$ Politik uang tersebut juga dilakukan dalam membeli dukungan partai-partai pendukung hingga jelas dicalonkan dari partai. ${ }^{57}$

\section{b. Kekurangan Pemilihan Kepala daerah oleh DPRD}

52 Pasal 191 ayat (1) Undang-Undang Nomor 7 Tahun 2017 tentang Pemilihan Umum

53 Pasal 188 ayat (2) Undang-Undang Nomor 7 Tahun 2017 tentang Pemilihan Umum

54Johnny Ibrahim, Op.Cit., hlm. 245.

55 Ahmad Rifa'I dan Sri Kusriyah, Peran Partai Politik Dalam Pengawasan Terhadap Kadernya Yang Duduk Di DPRD Untuk Meningkatkan Kualitas Perwakilan, Jurnal Hukum Khaira Ummah, Vol. 12. No. 4, Desember 2017, hlm. 981.

56 Jonasmer Simatupang dan Muhammad Subekhan, "Pengaruh Budaya Politik Uang dalam Pemilu Terhadap Keberlanjutan Demokrasi Indonesia", Seminar Nasional Hukum Universitas Negeri Semarang, Vol. 4, No. 3, 2018, hlm. 1302

57 Riwanto Titosudarmo, "Mencari Indonesia: Demografi Politik Pasca Soeharto", Jakarta: LIPI Press, 2007, hlm. 151.

Sayyidatul Insiyah; Xavier Nugraha; Shevierra Danmadiyah, Pemilihan Kepala Daerah Oleh Dewan Perwakilan Rakyat Daerah: Sebuah Komparasi Dengan Pemilihan Secara Langsung Oleh Rakyat 
Supremasi Hukum : Jurnal Penelitian Hukum

p-ISSN: 1693-766X ; e-ISSN: 2579-4663, Vol. 28, No. 2, Agustus 2019, 163-186

Pemilihan kepala daerah memilik tiga fungsi penting dalam penyelenggaraan pemerintahan daerah: Pertama, memilih kepala daerah yang sesuai dengan kehendak masyarakat di daerah sehingga diharapkan dapat memahami dan mewujudkan kehendak masyarakat di daerah; Kedua, melalui pemilihan kepala daerah diharapkan pilihan masyarakat di daerah didasarkan pada visi, misi, program serta kualitas dan integritas calon kepala daerah, yang sangat menentukan keberhasilan penyelenggaraan pemerintahan di daerah; dan Ketiga, pemilihan kepala daerah merupakan sarana pertanggungjawaban sekaligus sarana evaluasi dan kontrol publik secara politik terhadap seorang kepala daerah dan kekuatan politik yang menopangnya. 58 Berkaca pada adanya 3 (tiga) fungsi tersebut, pemilihan kepala daerah melalui DPRD akan sulit memenuhi hal-hal tersebut.

Dipilihnya kepala daerah oleh DPRD belum tentu dapat menjamin bahwa kepala daerah terpilih akan sesuai dengan kehendak masyarakat di daerah. Direktur Eksekutif Komite Pemantauan Pelaksanaan Otonomi Daerah (KPPOD), Robert Endi Jaweng, mengatakan bahwa DPRD akan lebih mementingkan kepentingannya, meskipun berseberangan dengan kepentingan rakyat. 59 Pada titik inilah, pelibatan masyarakat dalam proses pemilihan kepala daerah hampir sama sekali dikesampingkan. ${ }^{60} \mathrm{Hal}$ tersebut tidak terlepas dari latar belakang DPRD yang juga merupakan perwakilan kepentingan-kepentingan khusus tertentu. 61 Sehingga, tidaklah mustahil apabila para wakil rakyat di daerah tersebut masih dibayangbayangi oleh kepentingan politik semata dalam menjalankan amanahnya.

Di era demokrasi representasi sebagaimana dianut Indonesia saat ini, berbagai peristiwa yang terjadi dalam kelembagaan DPRD menunjukkan mulai timbulnya gejala krisis demokrasi representasi. Hal tersebut tentu menjadi sinyal negatif yang akan menggerus kepercayaan publik terhadap institusi demokrasi representasi. ${ }^{62}$ Kepercayaan publik tersebut semakin menurun dengan banyaknya kasus korupsi yang menimpa beberapa anggota DPRD. Sebagai contoh konkrit ialah adanya kasus 41 anggota DPRD Kota Malang yang terlibat dalam kasus dugaan suap

58 Janedjri M. Gaffar, Op.CIt., hlm. 93.

59 Komite Pemantauan Pelaksanaan Otonomi Daerah, Tolak Pemilihan Kepala Daerah oleh DPRD, https://www.kppod.org/berita/view?id=355, 5 September 2014, dikunjungi pada 18 Juli 2019.

60 Mustafa Lutfi, "Hukum Sengketa Pemilukada di Indonesia; Gagasan Perluasan Kewenangan Konstitusional Mahkamah Konstitusi”, Yogyakarta: UII Press, 2010, hlm. 127.

${ }^{61}$ Didik Sukriono, "Menggagas Sistem Pemilihan Umum di Indonesia", Jurnal Konstitusi Pusat Kajian Konstitusi Universitas Kanjuruhan Malang, 2009, hlm. 23.

62 Abdur Rozaki, Sunaji Zamroni, Titok Hariyanto, dan M. Zainal Anwar, Dari Representasi Simbolik Menuju Representasi Substantif, Yogyakarta: Institute for Research and Empowerment, 2014, hlm. 17.

Sayyidatul Insiyah; Xavier Nugraha; Shevierra Danmadiyah, Pemilihan Kepala Daerah Oleh Dewan Perwakilan Rakyat Daerah: Sebuah Komparasi Dengan Pemilihan Secara Langsung Oleh Rakyat 
Supremasi Hukum : Jurnal Penelitian Hukum

p-ISSN: 1693-766X ; e-ISSN: 2579-4663, Vol. 28, No. 2, Agustus 2019, 163-186

pembahasan APBD-P Kota Malang. ${ }^{63}$ Suatu hal yang ironi ketika para wakil rakyat yang telah mendapat legitimasi dari rakyat justru mengabaikan amanah yang diberikan rakyat.

Berangkat dari fakta yang ada, tentu masyarakat tidak akan secara penuh memberi kepercayaan kepada DPRD untuk dapat memilih kepala daerah yang kompeten serta sesuai dengan kehendak masyarakat. Ketidakpercayaan masyarakat terhadap pemilihan kepala daerah melalui DPRD tersebut, termanifestasikan dalam survei terakhir Litbang Kompas yang mendapati mayoritas responden, yaitu 87,6 persen, mengemukakan kepala daerah lebih baik dipilih langsung oleh rakyat. 64 Hanya 10,2 persen yang menilai pemilihan oleh DPRD lebih baik dan sisanya 2,2 tidak menjawab/tidak tahu. 65

Selain itu, pemilihan kepala daerah melalui DPRD akan menghilangkan satu ruang partisipasi masyarakat secara langsung dalam penyelenggaraan pemerintahan daerah melalui pemilihan kepala daerah. Paling tidak, akibat yang akan muncul adalah menjauhnya hubungan antara kepala daerah dengan masyarakat di daerah.66 Sehingga, nantinya sangat dimungkinkan rakyat di daerah tidak mengetahui visi dan misi dari kepala daerahnya. Pemilihan kepala daerah melalui DPRD juga akan cenderung menciptakan ketergantungan terhadap DPRD, sehingga nantinya kepala daerah lebih bertanggung jawab kepada DPRD daripada kepada rakyat.67 Padahal, esensi dari demokrasi adalah mendekatkan pemimpin dengan kepentingan dan kebutuhan rakyat yang dipimpinnya. 68

\section{PENUTUP \\ Simpulan}

Pemilihan umum sebagai sarana pengejawantahan kedaulatan rakyat faktanya memiliki kelebihan dan kekurangan. Melalui pemilihan umum, kepala daerah yang terpilih tentu akan memiliki ikatan yang lebih dekat dengan warga karena dalam hal ini, masyarakat daerah itu sendirilah yang menentukan figur yang akan memimpin

63 Haris Fadhil, "Perjalanan Kasus Korupsi 41 Anggota DPRD Malang Hingga PAW Massal", https://news.detik.com/berita/d-4206487/perjalanan-kasus-korupsi-41-anggotadprd-malang-hingga-paw-massal, 11 September 2018, dikunjungi pada 15 Juli 2019.

${ }^{64}$ Komite Pemantauan Pelaksanaan Otonomi Daerah, Tolak Pemilihan Kepala Daerah oleh DPRD, https://www.kppod.org/berita/view?id=355, 5 September 2014, dikunjungi pada 18 Juli 2019.

65 Ibid.

66 Janedjri M. Gaffar, Op.Cit., hlm. 136-137.

67 Rudi Hauter, "Pemilihan Langung Kepala Daerah: Transformasi Menuju Demokrasi Lokal", Jakarta: Asosiasi DPRD Kota Seluruh Indonesia dan Konrad Adenauer Stiftung, 2003, hlm. 106-107.

68 Andi Suhardiyanto dan Puji Lestari, "Partisipasi Politik Perempuan: Studi Perempuan dalam Pemilihan Kepala Daerah Jawa Tengah Tahun 2008", Forum Ilmu Sosial, Vol. 35 No. 2, Desember 2008, hlm. 95.

Sayyidatul Insiyah; Xavier Nugraha; Shevierra Danmadiyah, Pemilihan Kepala Daerah Oleh Dewan Perwakilan Rakyat Daerah: Sebuah Komparasi Dengan Pemilihan Secara Langsung Oleh Rakyat 
Supremasi Hukum : Jurnal Penelitian Hukum

p-ISSN: 1693-766X ; e-ISSN: 2579-4663, Vol. 28, No. 2, Agustus 2019, 163-186

daerahnya sendiri. Selain itu, derajat demokratis pemilihan kepala daerah akan lebih terasa ketika kepala daerah dipilih secara langsung oleh rakyat mengingat dengan adanya pemilihan langsung, partisipasi rakyat lebih diutamakan. Namun, di lain sisi, pemilihan kepala daerah secara langsung ternyata berdampak pada berbagai konflik yang timbul di masyarakat akibat gesekan-gesekan antara para pendukung calon kepala daerah yang merasa tidak puas dengan hasil pemilihan umum. Selain itu, faktor efisiensi anggaran dan waktu juga menjadi salah satu hal yang juga perlu diperhatikan pada saat dipilihnya mekanisme pemilihan secara langsung dalam menentukan kepala daerah. Adapun mekanisme kedua dalam pemilihan kepala daerah yaitu melalui pemilihan oleh DPRD. Pemilihan kepala daerah oleh DPRD memang dapat menekan anggaran politik yang dikeluarkan, namun pemilihan kepala daerah oleh DPRD tidak dapat menjamin bahwa kepala daerah yang dihasilkan mampu merepresentasikan pilihan rakyat, terlebih saat ini kepercayaan masyarakat terhadap lembaga perwakilan daerah tersebut mengalami degradasi akibat banyaknya anggota DPRD yang terbukti terlibat kasus korupsi. Mengacu pada berbagai kelebihan dan kelemahan dari masing-masing mekanisme pemilihan kepala daerah, maka mekanisme pemilihan kepala daerah yang lebih sesuai untuk diterapkan di Indonesia adalah melalui pemilihan umum. Meskipun pemilihan umum masih memiliki beberapa kelemahan, namun kelemahan-kelemahan tersebut tidak menjadikan dihapuskannya mekanisme pemilihan umum dalam proses penggantian jabatan kepala daerah di Indonesia.

\section{Saran}

Pemilu merupakan salah satu cara yang terbaik untuk melakukan proses penggantian jabatan dalam pemerintahan. Terkait berbagai kekurangan dalam pemilu dapat diatasi dengan berbagai langkah. Persoalan pendanaan dapat diatasi dengan melakukan pemilihan kepala daerah secara serentak. Dengan demikian akan tercipta efektifitas dan efisiensi baik dari segi anggaran maupun tenaga dan tidak menghilangkan prinsip esensial dari demokrasi. Berkaitan dengan konflik horizontal pasca pemilu, salah satu hal yang dapat dilakukan adalah dengan meningkatkan dan melakukan sosialisasi pendidikan politik terhadap masyarakat Indonesia akan pemahaman pemilihan umum.

\section{DAFTAR PUSTAKA}

Agustin, Oly Vina., 2018, "Jurisprudence Enforceability on Judicial Review Authority in the Constitutional Court Decision", Jurnal Konstitusi..

Ahmad Winarno, "Rp 817 Miliar, Anggaran untuk Pilkada Jatim 2018", https://regional.kompas.com/read/2017/06/03/12140131/rp.817.miliar.angg aran.untuk.pilkada.jatim.2018, 03 Juni 2017, dikunjungi pada 16 Juli 2019.

Sayyidatul Insiyah; Xavier Nugraha; Shevierra Danmadiyah, Pemilihan Kepala Daerah Oleh Dewan Perwakilan Rakyat Daerah: Sebuah Komparasi Dengan Pemilihan Secara Langsung Oleh Rakyat 
Supremasi Hukum : Jurnal Penelitian Hukum

p-ISSN: 1693-766X ; e-ISSN: 2579-4663, Vol. 28, No. 2, Agustus 2019, 163-186

Aji YK Putra, "2 Timses Calon di Pilkada Empat Lawang Dikabarkan Tewa", https://regional.kompas.com/read/2018/06/12/22040101/2-timses-calon-dipilkada-empat-lawang-bentrok-1-orang-dikabarkan-tewas?page=all, 12 Juni 2018, dikunjungi pada 16 Juli 2019.

Annan, Kofi A., 2012, Pendalaman Demokrasi: Strategi untuk Meningkatkan Integritas Pemilihan Umum di Seluruh Dunia, Geneva: Kofi Annan Foundation.

Aris, Muhammad Syaiful., 2018, "Penataan Sistem Pemilihan Umum Yang Berkeadilan Untuk Penguatan Sistem Presidensil Di Indonesia", Jurnal Yuridika.

Rifa'I, Ahmad., dan Sri Kusriyah, 2017, "Peran Partai Politik Dalam Pengawasan Terhadap Kadernya Yang Duduk Di DPRD Untuk Meningkatkan Kualitas Perwakilan", Jurnal Hukum Khaira Ummah.

Asshiddiqie, Jimly., 2009, Pengantar Imu Hukum Tata Negara, Jakarta: Raja Grafindo Persada.

Ashiddiqie, Jimly., 2009, Menuju Negara Hukum Yang Demokratis, Sekretariat Jenderal dan Kepaniteraan Mahkamah Konstiusi, Jakarta: Sekretariat Jendral Mahkamah Konstitusi.

Azhari, Adia Fitriaciada., 2004, "Reformasi Pemilu dan Agenda Konsolidasi Demokrasi: Perspektif Ketatanegaraan", Jurisprudence.

Barus, Zulfaidi, 2014, "Analisis Filosofis Tentang Peta Konseptual Penelitian Hukum Normatif Dan Penelitian Hukum Sosiologis”, Jurnal Dinamika Hukum.

Bayu Hermawan, "Berencana Bangun 7 Rumah Sakit, RS Mitra Incar Dana IPO Rp 4 Triliun", https://republika.co.id/berita/ekonomi/makro/15/02/27/nkfo4mberencana-bangun-7-rumah-sakit-rs-mitra-incar-dana-ipo-rp4-triliun, $\quad 27$ Februari 2015, dikunjungi pada 16 Juli 2019.

Dylan Aprialdo Rachman, "Modus Korupsi 32 Kepala Daerah yang Sudah Ditangkap KPK". https://nasional.kompas.com/read/2018/08/05/10101301/moduskorupsi-32-kepala-daerah-yang-sudah-ditangkap-kpk, 5 Agustus 2018 , dikunjungi pada tanggal 09 Oktober 2018.

Sayyidatul Insiyah; Xavier Nugraha; Shevierra Danmadiyah, Pemilihan Kepala Daerah Oleh Dewan Perwakilan Rakyat Daerah: Sebuah Komparasi Dengan Pemilihan Secara Langsung Oleh Rakyat 
Supremasi Hukum : Jurnal Penelitian Hukum

p-ISSN: 1693-766X ; e-ISSN: 2579-4663, Vol. 28, No. 2, Agustus 2019, 163-186

Dylan Aprialdo Rachman, "Kaleidoskop 2018: 29 Kepala Daerah Terjerat Kasus Korupsi”, https://nasional.kompas.com/read/2018/12/18/12495661/kaleido skop-2018-29-kepala-daerah-terjerat-kasus-korupsi?page=all, 18 Desember 2018, dikunjungi pada 18 Juli 2019.

Dye, Thomas R., 2010, Understanding Public Policy, New York: Pearson Education.

Ekawati, Esty., 2014, "Dari Representasi Politik Formal ke Representasi Politik NonElektoral”, Jurnal Penelitian Politik.

Entah, Aloysius R., 2016, "Indonesia: Negara Hukum yang Berdasarkan Pancasila”, Seminar Nasional Hukum.

Fatah, Eep Saefullah., 1997, Evaluasi Pemilu Orde Baru, Bandung: Mizan.

Gaffar, Janedjri M., 2012, Politik Hukum Pemilu, Jakarta: Konstitusi Press.

Hauter, Rudi., 2003, Pemilihan Langung Kepala Daerah: Transformasi Menuju Demokrasi Lokal, Jakarta: Asosiasi DPRD Kota Seluruh Indonesia dan Konrad Adenauer Stiftung.

Hoecke, M.V., 2011, Legal doctrine: Which Method(s) for What Kind of Discipline?, Oxford: HART Publishing.

Ibrahim, Johnny., 2009, Pendekatan Ekonomi terhadap Hukum, Surabaya: Institute Teknologi Sepuluh Nopember.

Jafrianto, 2016, "Eksistensi Pemilihan Dengan Model Kesepakatan Warga Dalam Sistem Pemilihan Umum Di Indonesia (Kajian Putusan Mahkamah Konstitusi Nomor 47-81/Phpu.A- Vii/2009 Tentang Perselisihan Hasil Pemilihan Umum)”, JOM Fakultas Hukum.

Jerry Omona, "Korban Tewas Akibat Pilkada Papua Capai 57 Orang", nasional.tempo.co/amp/382617/korban-tewas-akibat-pilkada-papua-capai-57orang, 8 Februari 2012, dikunjungi pada 08 Oktober 2018.

"Mendagri: 50 Tewas Akibat Kerusuhan Pemilu Kada", https://news.detik.com/berita/d-2208294/mendagri-50-tewas-akibatkerusuhan-pemilu-kada, 01 April 2013, dikunjungi pada 16 Juli 2019.

Sayyidatul Insiyah; Xavier Nugraha; Shevierra Danmadiyah, Pemilihan Kepala Daerah Oleh Dewan Perwakilan Rakyat Daerah: Sebuah Komparasi Dengan Pemilihan Secara Langsung Oleh Rakyat 
Supremasi Hukum : Jurnal Penelitian Hukum

p-ISSN: 1693-766X ; e-ISSN: 2579-4663, Vol. 28, No. 2, Agustus 2019, 163-186

Komite Pemantauan Pelaksanaan Otonomi Daerah, Tolak Pemilihan Kepala Daerah oleh DPRD, https://www.kppod.org/berita/view?id=355, 5 September 2014, dikunjungi pada 18 Juli 2019.

Kiagus Aulianshah, "Kepala Daerah Rajin Korupsi, Masyarakat Apolitis", https://beritagar.id/artikel/editorial/kepala-daerah-rajin-korupsi-masyarakatapolitis, 21 Desember 2015, dikunjungi pada 16 Juli 2017.

Lutfi, Mustafa., 2010, Hukum Sengketa Pemilukada di Indonesia; Gagasan Perluasan Kewenangan Konstitusional Mahkamah Konstitusi, Yogyakarta: UII Press.

Mahfud MD, Moh., 2007, Perdebatan Hukum Tata Negara Pasca Amandemen Konstitusi, Jakarta: Pustaka LP3ES Indonesia.

Mandasari, Zayanti., 2014, "Politik Hukum Pengaturan Masyarakat Hukum Adat (Studi Putusan Mahkamah Konstitusi”, Jurnal Hukum IUS QUIA IUSTUM.

Marijan, Kacung., 2005, Pemilihan Kepala Daerah Secara Langsung dan Demokratisasi di Daerah, Surabaya: Airlangga University Press.

Marwan, Ali, 2016, 'Pemilihan Kepala Daerah Yang Demokratis Berdasarkan Putusan Mahkamah Konstitusi Nomor 97/PUU-IX/2013', Jurnal Legislasi Indonesia, dikutip dari Jimly Asshiddiqie, 2009, Komentar Atas Undang-Undang Dasar Negara Republik Indonesia Tahun 1945, Jakarta: Sinar Grafika.

Muntoha, 2009, "Demokrasi dan Negara Hukum”, Jurnal Konstitusi.

Nugraha, Xavier et al., 2019, Penggunaan Sistem Noken Di Papua Sebagai Wujud Pemilihan Kepala Daerah yang Demokratis Dalam Persektif UUD 1945, Yogyakarta: Penerbit Harfeey.

Nugraha, Xavier et al., 2019, Rekonstruksi Batas Usia Minimal Perkawinan Sebagai Bentuk Perlindungan Hukum Terhadap Perempuan (Analisa Putusan MK No. 22/Puu-Xv/2017)", Lex Scientia.

Pamungkas, Sigit., 2009, Perihal Pemilu, Yogyakarta: Laboratorium Jurusan Ilmu Pemerintahan dan Jurusan Ilmu Pemerintahan Universitas Gadjah Mada.

Sayyidatul Insiyah; Xavier Nugraha; Shevierra Danmadiyah, Pemilihan Kepala Daerah Oleh Dewan Perwakilan Rakyat Daerah: Sebuah Komparasi Dengan Pemilihan Secara Langsung Oleh Rakyat 
Supremasi Hukum : Jurnal Penelitian Hukum

p-ISSN: 1693-766X ; e-ISSN: 2579-4663, Vol. 28, No. 2, Agustus 2019, 163-186

Pigome, Martha., 2011, "Implementasi Prinsip Demokrasi dan Nomokrasi dalam Struktur Ketatatanegaraan RI Pasca Amandemen UUD 1945”, Jurnal Dinamika Hukum

Rahardjo, Satjipto., 2007, Biarkan Hukum Mengalir, Jakarta: Kompas.

Republik Indonesia. 1974, Undang-Undang No. 5 Tahun 1974 tentang Pokok-Pokok Pemerintahan Daerah. Lembaran Negara RI Tahun 1974 Nomor 38, Tambahan Lembaran Negara Nomor 3037. Sekretariat Negara. Jakarta.

Republik Indonesia. 1999, Undang-Undang No. 39 Tahun 1999 tentang Hak Asasi Manusia. Lembaran Negara RI Tahun 1999 Nomor 165, Tambahan Lembaran Negara Nomor 3886. Sekretariat Negara. Jakarta.

Republik Indonesia. 1999, Undang-Undang No. 22 Tahun 1999 tentang Pemerintahan Daerah. Lembaran Negara RI Tahun 1999 Nomor 60, Tambahan Lembaran Negara Nomor 3839. Sekretariat Negara. Jakarta.

Republik Indonesia. 2004, Undang-Undang No. 32 Tahun 2004 tentang Pemerintahan Daerah. Lembaran Negara RI Tahun 2004 Nomor 125, Tambahan Lembaran Negara Nomor 4437. Sekretariat Negara. Jakarta.

Republik Indonesia. 2014, Undang-Undang No. 23 Tahun 2014 tentang Pemerintahan Daerah. Lembaran Negara RI Tahun 2014 Nomor 244, Tambahan Lembaran Negara Nomor 5587. Sekretariat Negara. Jakarta.

Republik Indonesia. 2015, Undang-Undang No. 1 Tahun 2015 tentang Penetapan Peraturan Pemerintah Pengganti Undang-Undang Nomor 1 Tahun 2014 tentang Pemilihan Gubernur, Bupati, Dan Walikota Menjadi Undang-Undang. Lembaran Negara RI Tahun 2014 Nomor 245, Tambahan Lembaran Negara Nomor 5588. Sekretariat Negara. Jakarta.

Republik Indonesia. 2016, Undang-Undang No. 10 Tahun 2016 tentang Perubahan Kedua atas Undang-Undang Nomor 1 Tahun 2015 tentang Penetapan Peraturan Pemerintah pengganti Undang-Undang Nomor 1 Tahun 2014 tentang Pemilihan Gubernur, Wupati, dan walikota menjadi Undang-Undang. Lembaran Negara RI Tahun 2016 Nomor 130, Tambahan Lembaran Negara Nomor 5898. Sekretariat Negara. Jakarta.

Sayyidatul Insiyah; Xavier Nugraha; Shevierra Danmadiyah, Pemilihan Kepala Daerah Oleh Dewan Perwakilan Rakyat Daerah: Sebuah Komparasi Dengan Pemilihan Secara Langsung Oleh Rakyat 
Supremasi Hukum : Jurnal Penelitian Hukum

p-ISSN: 1693-766X ; e-ISSN: 2579-4663, Vol. 28, No. 2, Agustus 2019, 163-186

Rozaki, Abdur et al., 2014, Dari Representasi Simbolik Menuju Representasi Substantif, Yogyakarta: Institute for Research and Empowerment.

Safyra Primadhyta, "Menteri Tjahjo: Pilkada Serentak Malah Boros Biaya", https://www.cnnindonesia.com/ekonomi/20180122132009-532-

270670/menteri-tjahjo-pilkada-serentak-malah-boros-biaya, 22 Januari 2018, dikunjungi pada 18 Juli 2019.

"Biaya Tinggi Pemilihan Kepala Daerah", https://kolom.tempo.co/read/1100242/biaya-tinggi-pemilihan-kepaladaerah/full\&view=ok, 25 Juni 2018, dikunjungi pada 18 Juli 2019.

Siahaan, Maruarar., 2009, Peran Mahkamah Konstitusi Dalam Penegakan Hukum Konstitusi", Jurnal Hukum.

Simamora, Janpatar., 2011, "Eksistensi Pemilukada Dalam Rangka Mewujudkan Pemerintahan Daerah Yang Demokratis", Jurnal Mimbar Hukum.

Simatupang, Jonasmer., dan Muhammad Subekhan, 2018, "Pengaruh Budaya Politik Uang dalam Pemilu Terhadap Keberlanjutan Demokrasi Indonesia”, Seminar Nasional Hukum Universitas Negeri Semarang.

Sonata, Depri Liber., 2017, "Metode Penelitian Hukum Normatif dan Empiris: Karakteristik Khas Dari Metode Meneliti Hukum”, Fiat Justitia Jurnal Ilmu Hukum.

Suhardiyanto, Andi dan Puji Lestari, 2008, "Partisipasi Politik Perempuan: Studi Perempuan dalam Pemilihan Kepala Daerah Jawa Tengah Tahun 2008", Forum Ilmu Sosial.

Sukriono, Didik., 2009, "Menggagas Sistem Pemilihan Umum di Indonesia”, Jurnal Konstitusi Pusat Kajian Konstitusi Universitas Kanjuruhan Malang,

Thaib, Dahlan., 2009, Ketatanegaraan Indonesia Perspektif Konstitusional, Yogyakarta: Total Media.

Thalhah, H.M., 2003, Dinamika Ketatanegaraan Indonesia di Era Reformasi, Bojonegoro: Fakultas Hukum Universitas Bojonegoro.

Tim Peneliti Sistem Pemilu, 1998, Sistem Pemilihan Umum di Indonesia, Jakarta: Lembaga Ilmu Pengetahuan Indonesia dan Pustaka Sinar Harapan

Sayyidatul Insiyah; Xavier Nugraha; Shevierra Danmadiyah, Pemilihan Kepala Daerah Oleh Dewan Perwakilan Rakyat Daerah: Sebuah Komparasi Dengan Pemilihan Secara Langsung Oleh Rakyat 
Supremasi Hukum : Jurnal Penelitian Hukum

p-ISSN: 1693-766X ; e-ISSN: 2579-4663, Vol. 28, No. 2, Agustus 2019, 163-186

Titosudarmo, Riwanto., 2007, Mencari Indonesia: Demografi Politik Pasca Soeharto, Jakarta: LIPI Press.

Undang-Undang Dasar Negara Republik Indonesia Tahun 1945.

Wati, Evi Purnama., 2015, "Pemilu Sebagai Wujud Kedaulatan Rakyat", E-Jurnal Hukum. 